\title{
Pengaruh Program Komunitas Usaha Mandiri (KUM) di Yayasan Dana Sosial Al Falah Surabaya terhadap Pendapatan UMKM
}

\author{
Erika Dwi Meilindasari ${ }^{1}$, Sri Abidah Suryaningsih ${ }^{2}$ \\ ${ }^{1}$ Fakultas Ekonomi, Universitas Negeri Surabaya \\ 2 Fakultas Ekonomi, Universitas Negeri Surabaya
}

\section{Article}

Information

History of article:

Received: 20-03-2019

Approved: 25-05-2019

Published: 30-06-2019

Keywords: $\quad$ UMKM

empowerment, Komunitas Usaha

Mandiri (KUM) program

UMKM income.

\begin{abstract}
The purpose of research to determine the effect of the Komunitas Usaha Mandiri (KUM) program at the Yayasan Dana Sosial Al Falah Surabaya to UMKM income. This research was conducted using quantitative methods with an associative approach with a sample of 73 Mustahiq. The test used in this study is a simple linear regression test, validity test, reliability test, T-test, and the coefficient of determination (R2) were processed using SPSS 22. The results of this study are the Komunitas Usaha Mandiri (KUM) program had a significant effect on the UMKM income of the Yayasan Dana Sosial Al Falah Surabaya.
\end{abstract}

\begin{abstract}
Abstrak
Tujuan artikel untuk mengetahui pengaruh Program Komunitas Usaha Mandiri (KUM) di Yayasan Dana Sosial Al Falah Surabaya terhadap pendapatan UMKM. Artikel ini menggunakan metode kuantitatif dengan pendekatan asosiatif dengan sampel berjumlah 73 mustahiq. Uji yang digunakan dalam artikel ini yaitu persamaan uji regresi linier sederhana, uji validitas, uji reliabilitas, uji $\mathrm{T}$ dan Koefisien Determinasi $\left(\mathrm{R}^{2}\right)$ diolah dengan menggunakan SPSS 22. Hasil dari artikel menyebutkan bahwa Program Komunitas Usaha Mandiri (KUM) berpengaruh signifikan terhadap pendapatan UMKM.
\end{abstract}

correspondence to: Sri Abidah Suryaningsih

ISSN 2527-7499 (print); 2528-3634 (online)

E-mail: sriabidah@unesa.ac.id

\section{PENDAHULUAN}

Kondisi pertumbuhan ekonomi global yang tumbuh lebih lambat di tahun 2019 ini dibandingkan pada tahun sebelumnya diperkirakan berdampak pada pertumbuhan ekonomi Indonesia dalam laporan Global Economic Prospect 2019 terbaru pada Januari 2019. Bank Dunia menaksirkan pada pertumbuhan ekonomi global saat ini hanya mecapai 2,9\% yang turun dari proyeksi pertumbuhan pada tahun 2018 sebesar 3\% (Worlbank, 2019). Perlambatan dalam ekonomi global ini dinilai sebagai dampak dari aktivitas manufaktur dan perdagangan sehingga dari beberapa negara berkembang harus menghadapi tekanan keuangan pasar. Sehingga, perlambatan dari pertumbuhan ekonomi yang akan berdampak pada laju penurunan angka kemiskinan di negara berkembang.

Kemiskinan hingga saat ini masih menjadi masalah utama dalam pembangunan nasional. Dilihat dari sisi jumlah, sebagaian besar dari penduduk miskin yang masih berada di Pulau Jawa yang berjumlah 13,19 juta penduduk (Badan Pusat Statistik, 2018). Dalam upaya yang sudah dilakukan oleh pemerintah untuk menanggulangi kemiskinan dengan melalui beberapa program yang diberikan belum juga memberikan dampak signifikan dalam menurunkan angka kemiskinan. 
Pada saat ini, Usaha Mikro, Kecil dan Menengah mempunyai peranan penting untuk perekonomian nasional. Usaha Mikro, Kecil dan Menengah pada kondisi krisis ekonomi saat ini dapat dikatakan sebagai penopang dalam sistem pemulihan pada perekonomian nasional. Fungsi serta peranan UMKM dirasa sangat penting,karena pada sektor ini tidak hanya sebagai mata pencaharian, melainkan juga memberikan lapangan pekerjaan secara langsung dan luas bagi masyarakat yang berpendidikan serta berketerampilan rendah sehingga diharapkan dapat menanggulangi angka pada kemiskinan sehingga dapat menurun. Oleh karena itu, salah satu cara dalam upaya memperluas dan mengembangkan Usaha Mikro, Kecil dan Menengah dalam perekonomian nasional saat ini salah satunya diperlukan serangkaian berupa pembinaan yang bersumber dari masalah keterbatasan informasi dan pengetahuan permodalan.

Beberapa usaha yang dilakukan oleh pemerintah untuk dapat mengembangkan dan meningkatkan kesejahteraan umat, khususnya dalam sektor produktif. Namun saat ini dalam pelaksanaannya masih banyak pelaku usaha yang belum mendapatkan bantuan tersebut, dikarenakan dari proporsi jumlah Usaha Mikro, Kecil dan Menengah yang begitu banyak serta keterbatasan pemerintah dalam pengelolaan pendistribusian bantuan dan keterbatasan itulah yang seharusnya dicarikan jalan keluar agar dalam sektor usaha mikro dapat menerima bantuan serta akan berujung pada pengentasan kemiskinan.

Perkembangan lembaga pengelolaan zakat di Indonesia saat ini berkembang cukup baik, sehingga lembaga pengelola zakat mampu bersaing dalam memberikan bantuan khususnya pada dana ZIS untuk meningkatkan kesejahteraan umat, salah satu cara yang dilakukan oleh lembaga syariah yaitu lembaga zakat dalam meningkatkan kesejahteraan masyarakat saat ini yaitu menyalurkan pinjaman dana kepada masyarakat yang membutuhkan. Seperti halnya, pada lembaga amil zakat nasional Yayasan Dana Sosial Al Falah Surabaya. Yayasan Dana Sosial Al Falah Surabaya ini dibentuk menjadi lembaga yang bertugas menghimpun, menyalurkan, dan mengefesiensikan dana zakat, infak dan shodaqah dengan menggunakan konsep yang profesional, amanah, serta terpercaya sesuai dengan ketentuan agama dan dengan tujuan pengelolaan dana ZIS dapat dirasakan oleh masyarakat, sehingga tercapai kesejahteraan umat.

Yayasan Dana Sosial Al Falah Surabaya memiliki program tersendiri agar dana yang disalurkan bukan hanya membantu mustahiq tetapi juga dapat meningkatkan pendapatan dengan melalui pemberdayaan UMKM dengan tujuan mensejahterakan mustahiq. Pemberdayaan ini terbentuk dalam program Komunitas Usaha Mandiri (KUM) dengan tujuan menyerahkan bantuan pinjaman modal usaha tanpa bunga dan jaminan pada UMKM di Surabaya secara bergulir, mendidik masyarakat untuk berinfak, menjauhkan masyarakat dari riba, serta dapat memberikan keterampilan usaha serta pendidikan agama yang dapat menciptakan pendapatan untuk masyarakat. Sasaran dari program ini yaitu donatur korban PHK dan kelompok pengusaha kecil yang kurang mampu di Surabaya. Pemberian modal yang diberikan dalam program ini yaitu dengan menggunakan akad Qardbul Hasan dimana lembaga memberikan pinjaman kepada usaha-usaha pada sektor kecil dengan jangka waktu yang sudah diperjanjikan tanpa mengharapkan keuntungan atau bagi hasil.

\section{KAJIAN LITERATUR}

Dari berbagai permasalahan dan hambatan yang dihadapi Usaha, Mikro, Kecil dan Menengah, pada masa pemerintahan presiden Susilo Bambang Yudhoyono, ia dapat meresmikan kredit bagi Usaha, Mikro, Kecil dan Menengah dengan bentuk penjamin Kredit Usaha Rakyat (KUR) yang bertujuan untuk mengembangkan kegiatan perekonomian guna pemberdayaan UMKM, meningkatkan akses pembiayaan dan mengembangkan UMKM (Putra, dkk., 2013). Dalam penerapan program pemerintah 
Kredit Usaha Rakyat (KUR) saat ini sudah berhasil diterapkan, tetapi belum maksimal dikarenakan pinjaman pemberian kredit pada program ini yang disalurkan dari perbankan masih membuat beban kepada pelaku UMKM dengan adanya bunga atau angsuran yang lebih besar dari jumlah nominal pinjaman sehingga membuat seseorang enggan akan meminjam dana di perbankan untuk modal usahanya.

Dalam mendorong pencapaian prioritas nasional dalam menanggulangi kemiskinan, instrumen zakat, infaq, dan shodaqah (ZIS) dituntut untuk dapat berperan dalam mengentaskan kemiskinan dan membawa kesejahteraan umat salah satunya yaitu zakat produktif. Zakat produktif merupakan suatu dana zakat yang disalurkan kepada mustahik dengan berupa modal digunakan untuk membantu dalam mengembangkan usahanya, sehingga usahanya dapat memenuhi kebutuhan hidupnya hingga jangka panjang. Menurut Fatmi, dan Suryaningsih (2019: 32) menjelaskan pendistribusian zakat produktif yakni sebagai modal yang diberikan kepada mustahiq agar mustahiq dapat mempunyai usaha sendiri serta pendapatan sendiri, sehingga yang mulanya mereka menjadi mustahiq bisa menjadi muzakki.

Salah satu kriteria UMKM yang layak untuk diberikan bantuan modal usaha oleh Yayasan Dana Sosial Al Falah Surabaya ini minimal usaha sudah berdiri selama satu tahun. Selain itu, pihak lembaga juga melakukan survei tempat tinggal dari pelaku UMKM yang akan diberikan bantuan pinjaman modal usaha. Yayasan Dana Sosial Al Falah Surabaya sudah menetapkan langkah tepat dalam program ini sehingga membuat para anggotanya merasa mudah dalam prosedur pembiayaan tanpa perlu terbebani dari biaya angsuran maupun agunan. Untuk mengetahui lebih lanjut maka perlu dianalisis apakah program Komunitas Usaha Mandiri (KUM) di Yayasan Dana Sosial Al Falah Surabaya berpengaruh terhadap pendapatan UMKM? Berdasarkan masalah pokok yang akan dicapai, maka hipotesis dalam artikel ini adalah $\mathrm{H}_{0}$ : Program Komunitas Usaha Mandiri (KUM) di Yayasan Dana Sosial Al Falah Surabaya tidak berpengaruh signifikan terhadap pendapatan UMKM. $\mathrm{H}_{1}$ : Program Komunitas Usaha Mandiri (KUM) berpengaruh signifikan terhadap pendapatan UMKM

\section{DATA DAN METODE}

Jenis dalam artikel ini yang digunakan yakni artikel kuantitatif dengan pendekatan asosiatif. Artikel kuantitatif dalam artikel ini digunakan untuk mengetahui apakah program Komunitas Usaha Mandiri (KUM) di Yayasan Dana Sosial Al Falah Surabaya berpengaruh terhadap pendapatan UMKM yang dilihat dari peningkatan pendapatan yang diperoleh mustahiq setelah menerima bantuan modal usaha dari Yayasan Dana Sosial Al Falah Surabaya. Jenis sumber data dalam artikel ini yang digunakan yaitu sumber data sekunder yang diperoleh dengan menyebarkan kuisioner kepada mustahiq Yayasan Dana Sosial Al Falah Surabaya khususnya mustahiq yang mengikuti program Komunitas Usaha Mandiri (KUM) berjumlah 73 mustahiq atau UMKM.

Artikel ini mendefinisikan operasional variabel yang terdiri dari dua variabel, yaitu: a) Variabel Independent, variabel independent pada artikel ini yaitu Program Komunitas Usaha Mandiri (KUM) di Yayasan Dana Sosial Al Falah Surabaya (X). Program dalam tulisan ini yaitu program yang diterapkan oleh Yayasan Dana Sosial Al Falah Surabaya guna meningkatkan pemberdayaan UMKM dengan tujuan meningkatkan perekonomian umat. b) Variabel Dependent, variabel dependent dalam artikel ini adalah pendapatan UMKM (Y). Pendapatan UMKM ditinjau dari jumlah pendapatan setelah didapat bantuan modal usaha dari program KUM serta lama usaha UMKM. Berikut ini tabel definisi operasional variabel pada artikel ini yaitu:

Teknik pengumpulan data pada artikel ini yakni dengan menggunakan kuisioner yang sudah di uji validitas serta uji reliabilitas. Teknis analisis data yang digunakan pada artikel ini yaitu analisis uji regresi linier sederhana dan uji $\mathrm{T}$ atau uji parsial serta koefisien determinasi $\left(\mathrm{R}^{2}\right)$ dan diolah dengan menggunakan aplikasi SPSS Statistics Versi 22. 
Tabel 1. Definisi Operasional Variabel

\begin{tabular}{|c|c|c|}
\hline Variabel & Teori & Indikator \\
\hline $\begin{array}{l}\text { Program } \\
\text { Komunitas } \\
\text { Usaha Mandiri } \\
\text { (X) }\end{array}$ & $\begin{array}{l}\text { a. Alhempi, } \\
2013 \\
\text { b. Anugrah, } \\
2013\end{array}$ & $\begin{array}{l}\text { a. Bantuan modal usaha } \\
\text { UMKM yang diterima oleh } \\
\text { mustahiq } \\
\text { b. Pembinaan yang dilakukan } \\
\text { dari Program Komunitas } \\
\text { Usaha Mandiri (KUM) }\end{array}$ \\
\hline $\begin{array}{l}\text { Pendapatan } \\
\text { UMKM (Y) }\end{array}$ & $\begin{array}{l}\text { Ash-Shadr, } \\
2008\end{array}$ & a. Peningkatan pendapatan \\
\hline
\end{tabular}

Sumber: data diolah

\section{ANALISIS dan HASIL}

\section{Hasil Uji Persyaratan}

Uji persyaratan yang digunakan adalah uji analisis regresi sederhana. Dalam artikel ini, uji analisis regresi linier sederhana digunakan untuk mengetahui ada atau tidaknya pengaruh variabel bebas yaitu Program Komunitas Usaha Mandiri (KUM) (X) terhadap variabel terikat yaitu pendapatan UMKM (Y). Berikut ini adalah tabel hasil analisis uji regresi linier sederhana dalam artikel ini, adalah sebagai berikut:

Tabel 2. Hasil Uji Regresi Linier Sederhana

Coefficients $^{a}$

\begin{tabular}{|c|c|c|c|c|c|}
\hline \multirow{2}{*}{ Model } & Unstandardized Coefficients & oefficients & $\begin{array}{l}\text { Standardized } \\
\text { Coefficients }\end{array}$ & \multirow[b]{2}{*}{$T$} & \multirow[b]{2}{*}{ Sig. } \\
\hline & B & Std. Error & Beta & & \\
\hline (Constant) & 2,004 & 1,799 & & 1,114 & 269 \\
\hline Program & & & & & \\
\hline Komunitas & & & & & \\
\hline Usaha & & & & & \\
\hline $\begin{array}{l}\text { Mandiri } \\
\text { (KUM) }\end{array}$ & ,559 & ,084 & 618 & 6,631 & ,000 \\
\hline
\end{tabular}

Berdasarkan pada Tabel 2, menunjukkan bahwa hasil uji regresi linier sederhana alpha (a) yaitu angka konstan dari unstandardized coefficients sebesar 2,004. Konstanta sebesar 2,004 memiliki arti bahwa nilai konsisten dari variabel pendapatan UMKM $(\mathrm{Y})$ sebesar 2,004. Sedangkan b adalah angka koefisien dapat diartikan bahwa nilai program Komunitas Usaha Mandiri (KUM) (X) sebesar 0,559. Sehingga, dapat disimpulkan bahwa koefisien tersebut memiliki nilai positif berarti program Komunitas Usaha Mandiri (KUM) (X) berpengaruh positif terhadap pendapatan UMKM $(\mathrm{Y})$ dan disimpulkan persamaan regresinya adalah $\mathrm{Y}=2,004+0,559 \mathrm{X}$. Nilai signifikansi didapat dari tabel Coefficients sebesar 0,000< 0,05 sehingga dapat disimpulkan variabel program Komunitas Usaha Mandiri (KUM) berpengaruh terhadap variabel pendapatan UMKM. 


\section{Uji Parsial atau Uji t}

Pada artikel Uji $t$ digunakan untuk mengetahui suatu pengaruh variabel $(\mathrm{X})$ terhadap variabel $(\mathrm{Y})$. Apabila $t_{\text {hitung }}$ lebih besar dari tabel maka variabel independen berhubungan dengan variabel dependen, begitu sebaliknya. Berikut tabel dari hasil Uji t atau uji parsial, adalah sebagai berikut:

Tabel 3. Hasil Uji t atau Uji Parsial

Coefficients $^{\mathrm{a}}$

\begin{tabular}{|c|c|c|c|c|c|}
\hline \multirow[t]{2}{*}{ Model } & \multicolumn{2}{|c|}{ Unstandardized Coefficients } & \multicolumn{3}{|l|}{$\begin{array}{l}\text { Standardized } \\
\text { Coefficients }\end{array}$} \\
\hline & $\mathbf{B}$ & Std. Error & Beta & $\mathbf{T}$ & Sig. \\
\hline (Constant) & 2,004 & 1,799 & & 1,114 & 269 \\
\hline Program & & & & & \\
\hline Komunitas & & & & & \\
\hline Usaha & & & & & \\
\hline $\begin{array}{c}\text { Mandiri } \\
\text { (KUM) }\end{array}$ &, 559 & 084 & ,618 & 6,631 & 000 \\
\hline
\end{tabular}

Berdasarkan pada tabel 3, diketahui thitung sebesar 6,631 dimana lebih besar dari nilai tabel yaitu sebesar 1,996 yang diperoleh dari distribusi nilai tabel. Sehingga, dapat disimpulkan bahwa program Komunitas Usaha Mandiri (KUM) berpengaruh terhadap pendapatan UMKM.

\section{Koefisien Determinasi $\left(\mathbf{R}^{2}\right)$}

Koefisien determinasi $\left(\mathrm{R}^{2}\right)$ digunakan untuk menunjukkan seberapa besar pengaruh dari variabel $(\mathrm{X})$ terhadap variabel $(\mathrm{Y})$. Berikut tabel hasil uji Koefisien Determinasi $\left(\mathrm{R}^{2}\right)$, adalah sebagai berikut:

Tabel 4. Hasil Uji Koefisien Determinasi $\left(\mathbf{R}^{2}\right)$ Model Summary

\begin{tabular}{ccccc}
\hline Model & $\mathbf{R}$ & R Square & $\begin{array}{c}\text { Adjusted R } \\
\text { Square }\end{array}$ & $\begin{array}{c}\text { Std. Error of } \\
\text { the Estimate }\end{array}$ \\
\hline 1 &, $618^{\mathrm{a}}$ &, 382 &, 374 & 1,34865 \\
\hline
\end{tabular}

a. Predictors: (Constant), Program KUM

Berdasarkan pada tabel 4, diketahui nila $\mathrm{R}^{2}$ yaitu sebesar 0,382 dan dapat diartikan bahwa variabel program Komunitas Usaha Mandiri (KUM) memberikan pengaruh dengan presentase 38,2\% terhadap variabel pendapatan UMKM, sedangkan untuk sisanya sebesar 0,618 dengan presentase 61,8\% yang dipengaruhi oleh faktor lain dimana tidak diteliti pada artikel ini.

\section{Pengaruh Program Komunitas Usaha Mandiri (KUM) di Yayasan Dana Sosial Al Falah Surabaya Terhadap Pendapatan UMKM}

Berdasarkan dari hasil artikel, program Komunitas Usaha Mandiri (KUM) berpengaruh signifikan terhadap pendapatan UMKM. Dalam hal ini sesuai dengan artikel terdahulu yang dilakukan oleh Riawan, dkk (2018) mendapatkan hasil artikel bahwa Kredit Usaha Rakyat (KUR) berpengaruh signifikan terhadap pendapatan usaha. Terdapat 2 indikator di dalam variabel program Komunitas Usaha Mandiri (KUM) ini dalam mengukur ada atau tidaknya pengaruh terhadap pendapatan UMKM, yakni bantuan modal usaha yang diterima oleh mustahiq dan pembinaan yang dilakukan dari program Komunitas Usaha Mandiri (KUM). Dilihat dari jawaban 73 responden menunjukkan jawaban positif yaitu setuju dan sangat setuju. Dengan berarti bantuan atau pinjaman yang diberikan sangat berpengaruh pada pengembangan usahanya. Sehingga dapat dikatakan setiap jumlah dana pinjaman 
atau bantuan yang disalurkan besar, maka akan memberikan jumlah pendapatan UMKM yang didapatkan juga besar (Halid, dkk, 2014). Dalam suatu usaha apabila seseorang memilih tindakan untuk pembiayaan atas pinjaman, maka dari setiap waktu yang sudah diperjanjikan atau ditetapkan wajib membayar atas pinjamannya. Selanjutnya, dalam proses pengembalian cicilannya lancar dan modal mengalami kenaikan, maka dapat dipastikan bahwa penghasilan atau pendapatan seseorang yang diperoleh mengalami sebuah peningkatan (Husnan, 1998).

Indikator kedua dari variabel program Komunitas Usaha Mandiri (KUM) yaitu pembinaan yang dilakukan dari program Komunitas Usaha Mandiri (KUM) di Yayasan Dana Sosial Al Falah Surabaya. Sebagaimana dalam teori Mathis (2012) dijelaskan bahwa pembinaan yang dilakukan adalah salah satu untuk mencapai kemampuan tertentu. Indikator pembinaan ini juga didukung dari artikel Irawati (2018) bahwa usaha kecil saat ini menjadi kegiatan ekonomi rakyat yang mempunyai peran sentral di dalam perekonomian Indonesia. Selain itu dijelaskan pada artikel Alhempi (2013) pembinaan merupakan suatu proses atau proses pengembangan yang mencakup urutan pengertian, diawali dengan mendirikan, menumbuhkan, memelihara pertumbuhan yang disertai usaha perbaikan dan menyempurnakan serta mengembangkannya.

Menurut pandangan Islam, harta yang dimiliki seorang muslim yaitu harga yang diperoleh dengan cara yang halal, tidak mengandung unsur penipuan dan riba untuk digunakan memenuhi kebutuhan, salah satunya untuk dijadikan modal usaha dalam kegiatan ekonomi atau perdagangan. Manusia juga diharapkan dalam melakukan kegiatan ekonomi, khususnya dalam jual beli atau perniagaan arus sesuai dengan syariah, tidak hanya mencari keuntungan melainkan dengn mencari keridhoan Allah SWT. Pernyataan tersebut diperkuat oleh Q.S An-Nisa' ayat 29:
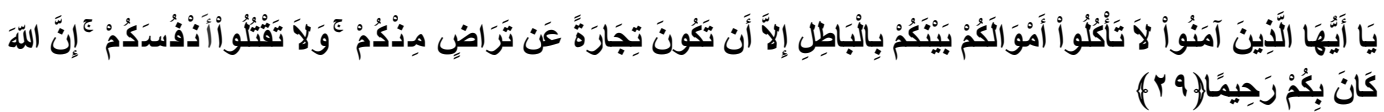

'Wahai orang-orang yang beriman! Janganlah kamu saling memakan harta sesamamu dengan jalan yang batil (tidak benar), kecuali dalam perdagangan yang berlaku atas dasar suka sama suka diantara kamu dan janganlah kamu membunuh dirimu. Sungguh Allah Maha Penyayang kepadamu".

Menurut perspektif hukum Islam, dalam pendapatan yang baik merupakan pendapatan dimana pendapatan yang diperoleh dengan halal, terhindar dari kegiatan perniagaan yang terhindar dari hal-hal yang haram, seperti gbabn fahisy, ibtikar, ghisy, gbarar, dan tadlis. Indikator yang digunakan untuk mengukur variabel yaitu peningkatan pendapatan yang diterima mustahiq sesudah menerima bantuan modal usaha dari Yayasan Dana Sosial Al Falah Surabaya. Maka diperoleh dari jawaban kuisioner 73 responden rata-rata menjawab setuju dan sangat setuju, sehingga dapat disimpulkan bahwa rata-rata dari 73 responden dapat mengembangkan usahanya dan mustahiq mengalami peningkatan pendapatan setelah menerima bantuan pinjaman modal untuk usahanya dari Yayasan Dana Sosial Al Falah Surabaya melalui program Komunitas Usaha Mandiri (KUM).

Pelaksanaan pada program Komunitas Usaha Mandiri (KUM) di Yayasan Dana Sosial Al Falah Surabaya dalam artikel yang sudah dilakukan dapat menunjukkan suatu tingkat terwujudnya suatu keberhasilan dimana program disalurkan tepat sasaran. Hal itu dapat ditunjukkan dimana angka peningkatan pendapatan yang dijadikan sampel dalam artikel ini menunjukkan rata-rata mustahiq dapat mengembangkan usahanya dan mengalami peningkatan pendapatan setelah menerima bantuan modal usaha. Selain itu program ini juga dapat mengubah status yang awalnya menjadi mustahiq hingga menjadi muzakki dengan memberikan infaq sukarela kepada Yayasan Dana Sosial Al Falah Surabaya. 
Program Komunitas Usaha Mandiri (KUM) dalam pelaksanaanya sudah sesuai dan tidak melanggar syarat dan rukun maupun ketentuan di dalam menjalankan suatu akad Qardhul Hasan. Sehingga sejauh masa pelaksanaanya, program ini telah memberikan implikasi yang baik bagi masyarakat sekitar seperti hal nya menjadikan anggota atau mustahiq dapat menjadi mandiri, dapat menciptakan usaha yang berkembang, dapat membantu masyarakat di dalam pemenuhan bantuan untuk pengembangan usaha, serta dapat meningkatkan pendapatan usaha anggota binaan Yayasan Dana Sosial Al Falah Surabaya daripada pendapatan sebelumnya. Sehingga kesejahteraan yang didapatkan mustahiq tidak hanya didalam segi ekonomi saja namun dari semua segi kehidupan sehingga dapat membuat perubahan yang lebih baik untuk kehidupan mustahiq kedepannya (Fatmi dan Suryaningsih, 2019).

\section{SIMPULAN}

Dari hasil analisis dapat disimpulkan bahwa program Komunitas Usaha Mandiri (KUM) di Yayasan Dana Sosial Al Falah Surabaya berpengaruh signifikan terhadap pendapatan UMKM. Hasil yang diperoleh dari pengolahan data dengan analisis regresi sederhana menunjukkan bahwa Program KUM (Komunitas Usaha Mandiri) di Yayasan Dana Sosial Al Falah Surabaya berpengaruh signifikan terhadap pendapatan UMKM. Sedangkan berdasarkan uji parsial atau uji t, $\mathrm{H}_{0}$ yang menyatakan bahwa Program KUM (Komunitas Usaha Mandiri) di Yayasan Dana Sosial Al Falah Surabaya tidak berpengaruh terhadap pendapatan UMKM ditolak, sedangkan $\mathrm{H}_{1}$ yang menyatakan bahwa Program KUM (Komunitas Usaha Mandiri) di Yayasan Dana Sosial Al Falah Surabaya berpengaruh terhadap pendapatan UMKM diterima. Berdasarkan hasil uji t, menunjukkan bahwa variabel program Komunitas Usaha Mandiri (KUM) berpengaruh signifikan terhadap pendapatan UKM.

Program KUM (Komunitas Usaha Mandiri) di Yayasan Dana Sosial Al Falah Surabaya dengan indikator bantuan modal usaha yang diterima oleh mustahik dapat dilihat dari Jawaban kuisioner 73 responden dari indikator tersebut menunjukkan jawaban positif yaitu setuju dan sangat setuju, berarti bantuan atau pinjaman yang diberikan sangat berpengaruh pada pengembangan usahanya. dan indikator pembinaan yang dilakukan dari Program Komunitas Usaha Mandiri (KUM) berpengaruh signifikan terhadap pendapatan UMKM dengan indikator pendapatan yakni peningkatan pendapatan setelah menerima bantuan modal usaha yang diberikan oleh Yayasan Dana Sosial Al Falah Surabaya dalam usahanya.

\section{Saran}

Untuk artikel selanjutnya, penulis mengharapkan mengenai pengaruh program Komunitas Usaha Mandiri (KUM) di Yayasan Dana Sosial Al Falah Surabaya terhadap pendapatan UMKM dapat ditambahkan pada variabel $(\mathrm{X})$ maupun variabel $(\mathrm{Y})$ agar dapat menjelaskan serta mengetahui secara luar khususnya pada program Komunitas Usaha Mandiri (KUM) di Yayasan Dana Sosial Al Falah Surabaya dengan hasil artikel agar dapat dijadikan sebagai simpulan umum serta pembanding.

\section{REFERENCES}

Alhempi, Raden Rudi dan Wismar Harianto. 2013. Pengaruh Pelatihan dan Pembinaan terhadap Pengembangan Usaha Kecil pada Program Kemitraan Bina Lingkungan. Media Riset Bisnis dan Manajemen. Vol. 13 (1)

Fatmi, dan Suryaningsih. 2019. Pengaruh Program Sentra Ternak (STM) Terhadap Kesejahteraan Mustahiq Pada LAZ Ummul Quro Jombang. Jurnal Ekonomi Islam. Vol. 2 (2)

Halid, dkk. 2014. Pengaruh Jumlah Kredit dan Suku Bunga Terhadap Pendapatan Usaha Mikro di BRI Unit Kabila. Jurnal Perspektif Pembiayaan dan Pembangunan Daerah. Vol. 1 (3) 
Husnan, Suad. 1998. Manajemen Keuangan. Yogyakarta: BPFE

Irawati, Rina. 2018. Pengaruh Pelatihan dan Pembinaan Terhadap Pengembangan Usaha Kecil. Jurnal JIBEKA. Vol. 12 (1)

Mathis, Robert L, dkk. 2012. Manajemen Sumber Daya Manusia Buku 1, Alib Bahasa: Jimmy Sadeli dan Bayu Prawira Hie. Jakarta. Salemba Empat

Putra, dkk. 2013. Efektivitas dan Dampak Program Bantuan Kredit Usaha Rakyat (KUR) Terhadap Pendapatan dan Kesempatan Kerja Usaha Mikro Kecil dan Menengah (UMKM) di Kota Denpasar. E-Jurnal EP Unud. Vol. 2 (10)

Riawan, dkk. 2018. Pengaruh Modal Sendiri dan Kredit Usaha Rakyat (KUR) Terhadap Pendapatan Usaha (Studi pada UMKM di Desa Platihan Kidul Kec. Siman). Jurnal Akuntansi dan Pajak. Vol. 19 (01)

Undang-Undang Republik Indonesia Nomor 23 Tahun 2011 tentang Pengelolaan Zakat bttps://www.worldbank.org/in/news/press-release/2019/01/08/darkening-prospects-global-economy-to-slow-to-29percent-in-2019-as-trade-investment-weaken (diakses tanggal 7 Maret 2019)

https://wnw.bps.go.id/pressrelease/2019/01/15/1549/persentase-penduduk-miskin-pada-september-2018-sebesar9-66-persen.btml

(diakses tanggal 15 Mei 2019) 